\title{
Population Recovery of Black-tailed Prairie Dogs Following Control with Zinc Phosphide
}

\author{
CRAIG J. KNOWLES
}

\begin{abstract}
This study evaluated the efficacy of $2 \%$ zinc phosphide grain bait as a control agent for black-tailed prairie dogs (Cynomys ludovicianus) and the rate at which prairie dogs returned to treated areas. Visual counts of prairie dogs closely corresponded to actual population trends and were chosen as the technique to evaluate changes of prairie dog numbers. Treatment of all of 2 , and portions of 5 , prairie dog colonies with zinc phosphide grain bait between $30 \mathrm{July}$ and 25 August 1978 resulted in an average of $85 \%$ (range 65 to 95\%) reduction in prairie dog numbers. Best results were obtained in the 2 colonies treated totally. The 2 colonies treated along the perimeter had the lowest percentage decrease in numbers of prairie dogs and were among the treatment types with the fastest population recovery. Prairie dogs returned to pretreatment levels within 1 year posttreatment at 1 colony. After 2 years posttreatment, 3 other colonies were approaching pretreatment population levels. Three to 5 years posttreatment appeared to be needed to obtain pretreatment numbers in the $\mathbf{2}$ colonies treated totally.
\end{abstract}

Control of black-tailed prairie dogs (Cynomys ludovicianus) is often considered economically feasible because it is thought to provide more forage to livestock. Marsh (1967) considered a $90 \%$ reduction in rodent populations necessary to achieve satisfactory relief from economic damage. In general, studies have found grain baits treated with strychnine or zinc phosphide to be effective at reducing prairie dog numbers to levels considered efficacious (Tietjen 1976, Sullins 1977, 1980a,b, Tietjen and Matschke 1982). There is little information available, however, to indicate how rapidly prairie dogs return to treated areas following substantial population reductions. Deer mice (Peromyscus maniculatus) invaded treated areas so rapidly as to negate any economic benefits of control (Gashwiler 1969, Pank and Matschke 1972, Sullivan 1979). The rate of population recovery following control with toxicants is important in the assessment of the cost/benefit ratio of such projects (Collins et al. 1984). The purpose of this study was to evaluate the efficacy of zinc phosphide grain bait as a control agent for black-tailed prairie dogs and to determine the rate of population recovery in treated areas.

\section{Study Area and Methods}

This study was conducted on the Charles M. Russell National Wildlife Refuge in northeastern Montana from 1978 to 1980 . Brief visits to the study area were made in July 1983 and April 1985. The Refuge was typified by rough, broken country interspersed with rolling prairie. Prairie dog colonies on the Refuge were restricted to the shrub-grassland and grassland habitats located on broad level ridge tops or on bottomlands of the major drainages. The management goal of the Refuge for prairie dogs at the time was to control the size of certain prairie dog colonies but not to exterminate them.

Seven prairie dog colonies at the western end of the Refuge north of the Missouri River were selected for experimental control with zinc phosphide bait. In 1978, I applied $2 \%$ zinc phosphide grain

\footnotetext{
Author is wildlife biologist, Fauna West Wildlife Consultants, P.O. Box 221, Bridger, Mont. 59014. At the time of the research, the author was research assistant, Montana Cooperative Wildlife Research Unit, University of Montana, Missoula 59812 .

Research was funded by the U.S. Fish and Wildlife Service, Refuge Division. The author wishes to thank Dr. B. O'Gara for technical advice and guidance in all phases of this study, and S. Gieb, R. Gumtow, P. Knowles, S. Schmidt, D. Schuster, and C. Stoner for field assistance.

Manuscript accepted 12 September 1985
}

bait at the 7 colonies following EPA label instructions (Tietjen 1976). A heaping teaspoon of steam-rolled oats (prebait) was placed as a 15-cm bait spot at the burrow opening of each mound in the section of the colony slated to be poisoned. This procedure was repeated 48 hours later with the treated grain bait. Four treatment patterns were used: (1) total reduction; in 2 colonies, bait was distributed throughout the entire colony; (2) perimeter reduction; perimeters of 2 colonies were treated with bait; (3) center reduction; bait was placed in the central areas of 2 colonies; and (4) split reduction; in 1 large colony ( $307 \mathrm{ha}$ ); bait was distributed in 2 broad bands ( $300 \mathrm{~m}$ wide) through the colony to split it into 3 sections. All 7 colonies were treated between $30 \mathrm{July}$ and 25 August 1978. Treated areas ranged from 5 to $33 \mathrm{ha}$; representing 11 to $100 \%$ of the colony area being treated. Each treated colony was searched between 24 and $\mathbf{4 8}$ hours posttreatment for prairie dogs dying above ground.

Visual counts of prairie dogs were chosen as the method to assess the immediate population consequences of poisoning and follow population recovery. Prairie dogs were counted in a specified area 5 times at 15-minute intervals on each of 3 different morning or evening activity periods. The largest of the 15 counts was then selected as the number that most closely approximated the actual number of prairie dogs in the count area. Accuracy of this census method was evaluated by live-trapping and marking (black fur dye and toe clipping) prairie dogs in 2 other colonies. During any trapping period nearly all prairie dogs were trapped and marked, making total enumeration possible. In colony $A(3 \mathrm{ha})$, prairie dogs were trapped and marked throughout the colony while in colony $B$ (16.4 ha) prairie dogs were studied only in a 2.5 -ha area of the colony. Immediately following completion of each trapping and marking period, visual counts were made in each colony (study area only in colony B) according to the above procedures. In colony A, census evaluations were conducted in 1978 August, 1979 June and October, and 1980 July; while in colony B, the survey periods were 1978 July and August; 1979, May, July, and October; and 1980 July.

Visual counts of prairie dogs were made within staked areas (2-8 ha) of the treated and untreated portion of each colony receiving partial reduction. In these colonies, the count areas were located $30-60 \mathrm{~m}$ within a treated or untreated area. For the 2 colonies receiving the total reduction treatment, visual counts were made throughout the entire colony. Colony B was selected to serve as a control for these 2 colonies. Counts were conducted at all colonies immediately pre- and posttreatment 1978, and again in 1979 August, and $1980 \mathrm{July}$. In addition, visual counts were made in 1979 May at all colonies receiving total and perimeter reductions and at 1 colony receiving center reduction. Percentage reduction in prairie dog numbers was determined using the following formula.

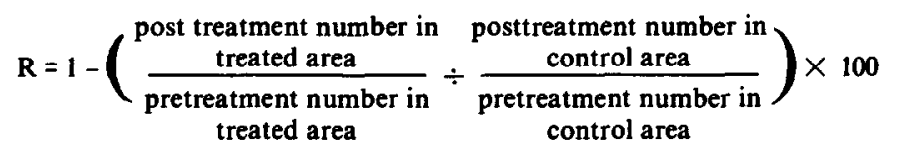

\section{Results}

Visual counts of prairie dogs at colonies A and B were highly correlated with actual population trends in the census areas $\left(r_{s}=0.986\right.$ and 0.943 colony A and B, respectively, $p<0.05$, Spear- 
man rank correlation coefficient). An average of $86 \pm$ SE $8 \%$ (range 67-96\%) of the animals present were observed using the maximum count. Following the application of the zinc phosphide grain bait at the 7 colonies, reduction in maximum counts relative to the controls averaged $85+\mathrm{SE} 10 \%$ (range 65-95\%) (Table 1). Poorest results were obtained in the 2 colonies receiving perimeter reduction $(\bar{X}=74 \%)$ while the best results were obtained in the 2 colonies receiving the total reduction treatment $(\bar{X}=95 \%)$. Density of prairie dogs dying above ground ranged from 0.2 / ha to 1.7 / ha and was correlated with density of prairie dogs in the treated area (Table 1) $\left(r_{0}=0.679, p=0.05\right.$, Spearman rank correlation coefficient). Using these density estimates, an average of $12 \%$ (range 5-19\%) of the prairie dogs died above ground. At least 7 of the 67 prairie dogs dying above ground were scavenged (avian and mammalian predators) 24 to $\mathbf{4 8}$ hours after poison application.

Table 1. Population reduction at seven prairie dos colonies following treatment with $2 \%$ zinc phosphide grain bait. Percentage of colony treated in parenthesis.

\begin{tabular}{lcccc}
\hline \hline & & \multicolumn{2}{c}{ Density (dogs/ha) } & \\
\cline { 3 - 4 } $\begin{array}{l}\text { Treatment } \\
\text { pattern }\end{array}$ & $\begin{array}{c}\text { Hectares } \\
\text { treated }\end{array}$ & $\begin{array}{c}\text { Live pre- } \\
\text { treatment }\end{array}$ & $\begin{array}{c}\text { Dead above } \\
\text { ground }\end{array}$ & $\begin{array}{c}\text { Percentage } \\
\text { reduction }\end{array}$ \\
\hline Total & $13.6(100)$ & 13.0 & 0.7 & 95 \\
Total & $6.4(100)$ & 9.1 & 1.7 & 95 \\
Perimeter & $10.0(59)$ & 14.6 & 1.2 & 65 \\
Perimeter & $8.9(41)$ & 4.2 & 0.7 & 83 \\
Center & $17.2(17)$ & 5.4 & 0.9 & 89 \\
Center & $5.0(29)$ & 13.1 & 1.6 & 86 \\
Split & $32.9(11)$ & 2.8 & 0.2 & 84 \\
\hline
\end{tabular}

"Estimate based on maximum count divided by census area.

Recolonization of treated areas varied greatly within and among treatment types (Table 2). One colony receiving perimeter reduction obtained pretreatment numbers within 1 year posttreatment. After 2 years posttreatment, the other perimeter reduction, the

Table 2. Population recovery of prairie dogs following control with $2 \%$ zine phosphide grain bait. Figures are expressed as a percentage of the pretreatment population relative to the control.

\begin{tabular}{|c|c|c|c|c|c|c|}
\hline \multicolumn{2}{|c|}{$\begin{array}{c}\text { Pre- } \\
\text { Treatment } \underline{\text { treatment }}\end{array}$} & \multicolumn{5}{|c|}{ Posttreatment } \\
\hline pattern & July 78 & Aug. 78 & May 79 & Aug. 79 & July 80 & July 83 \\
\hline Total & 100 & 5 & 10 & 13 & 32 & $96^{\circ}$ \\
\hline Total & 100 & 5 & 14 & 12 & 58 & $138^{\circ}$ \\
\hline Perimeter & 100 & 35 & 38 & 46 & 77 & \\
\hline Perimeter & 100 & 17 & 52 & 119 & 123 & \\
\hline Center & 100 & 11 & 22 & 23 & 25 & \\
\hline Center & 100 & 14 & & 62 & 72 & \\
\hline Split & 100 & 16 & & 56 & 97 & \\
\hline
\end{tabular}

"Figure is a percentage of the original pretreatment population in treated colony. The control colony suffered a severe population decline in 1982 as a result of other studies.

split reduction, and 1 center reduction colony were approaching pretreatment population levels. At least 1 and possibly 2 or more additional years appeared necessary for the 2 colonies receiving total reduction and the other center reduction colony to obtain pretreatment population levels. The average yearly per capita growth rate $\left(\mathrm{N}_{\mathrm{t}}=\mathrm{N}_{\mathrm{o}} \mathrm{e}^{\mathrm{rt}}\right.$, Southwood 1978: 370$)$ for the 2 colonies receiving the total reduction treatment was $r=0.916,1.069$, and 0.350 for 1978 to 1979,1979 to 1980 , and 1980 to 1983 , respectively. The average yearly per capita growth rate for the 5 colonies receiving partial reduction treatments was $r=1.339$ for 1978 to 1979 and 0.148 for 1979 to 1980 . Counts made in May 1979 prior to emergence of pups indicated that there was an increase of prairie dogs in all treatment types inventoried. Immigration of prairie dogs into treated areas appeared to be the cause for this in the colonies receiving partial reductions. The increase in the colonies receiving total reduction appeared to be an artifact of greater over-winter survival of prairie dogs in the treated colonies as compared to the control colony since maximum counts changed little from 1978 August to 1979 May in the treated colonies.

\section{Discussion}

The levels of control that I obtained with zinc phosphide poison were comparable to those obtained by Tietjen (1976), Sullins (1977, 1980 a,b), and Tietjen and Matschke (1982) using zinc phosphide grain bait on prairie dogs. This was despite record precipitation ( $57.1 \mathrm{~cm}$, water year) in 1978 resulting in abovenormal herbage production which is generally considered to reduce bait acceptance among ground-dwelling sciurids (Sullins and Verts 1978, Matschke et al. 1982). The greater reductions obtained at the 2 colonies with total reduction when compared to colonies with partial reductions suggest that the 30-60-m buffer zone between count areas and treatment boundaries did not completely prevent one treatment from influencing the other. The net effect of this experimental error would be to bias the results such that percentage reductions appeared lower than they actually were. Matschke et al. (1982) reported similar problems with a buffer strip of $30.5 \mathrm{~m}$ with Richardson's ground squirrel (Spermophilus richardsonii).

Despite substantial reductions in numbers, prairie dogs appeared capable of reaching pretreatment population levels in as few as 1 to 2 years where sizeable portions of the colonies were not treated. Even where the entire colonies were treated and population reduction was $95 \%$, pretreatment populations appeared to be attained from 3 to 5 years posttreatment. Malloy (1981) found that Columbian ground squirrels (S. columbianus) totally extirpated from an area with 1080 grain bait were able to attain $20 \%$ of their pretreatment population within 1 year. Matschke et al. (1982) found Richardson's ground squirrel populations in areas treated with zinc phosphide attained approximately 52 and $70 \%$ of their pretreatment levels relative to controls within 1 year in 2 studies. Both authors attributed this increase in the treated areas largely to immigration. The more rapid recolonization in the perimeter reduction treatment as opposed to the other treatment types in my study was probably related to the normal dispersal of prairie dogs from the center of the colony toward the perimeter (Garrett 1982).

I mapped all 7 of the treated colonies again in April 1985 and found that they were at or slightly larger than their original size in 1978. Topography and vegetation appeared more important in influencing the size of the colonies than did any specific treatment. Although baiting the center of the colony appeared to have longer lasting population consequences than perimeter control, it did not serve to keep either colony from expanding even during the first year posttreatment. If control of the size of a prairie dog colony is a management goal and toxicants are selected as the control method, total reduction appears to be the treatment that will most likely limit the growth of a colony on a short-term basis.

Merriam (1966) demonstrated that under the most favorable conditions $r_{m}$ (maximum intrinsic rate of increase) could barely exceed 1.0 for black-tailed prairie dogs. The initial rates of increase for prairie dogs in the colonies receiving total reduction, where immigration could be largely discounted as a source of new prairie dogs, were very close to this estimate. In contrast, using survivorship data from colony $B$ from 1978 to 1980 and in-uteral reproductive information from 148 female prairie dogs collected in 6 other prairie dog colonies during the same period (Knowles 1982) I estimated the maximum per capita growth rate for prairie dogs in this area to be $\mathbf{0 . 4 1 2}$. This information suggests that prairie dogs remaining after substantial population reduction by rodenticides have increased survival and/or reproductive rates.

\section{Literature Cited}

Collins, A.R., J.P. Workman, and D.W. Uresk. 1984. An economic analysis of black-tailed prairie dog (Cynomys ludovicianus) control. J. Range Manage. 37:358-361. 
Garrett, M.G. 1982. Dispersal of black-tailed prairie dogs in Wind Cave National Park, South Dakota. M.S. Thesis, Iowa State Univ., Ames.

Gashwiler, J.S. 1969. Deer mouse repopulation of a poisoned Douglas-fir clear cut. J. Forest. 67:494-497.

Knowles, C.J. 1982. Habitat affinity, populations and control of blacktailed prairie dogs on the Charles $M$. Russell National Wildlife Refuge. Ph.D. Diss., Univ. of Montana, Missoula.

Malloy, J.C. 1981. The effect of 1080 baiting on Columbian ground squirrels and nontarget mammal and bird populations. M.S. Thesis Univ. of Montana, Missoula.

Marsh, R.E. 1967. A guide for aerial baiting of ground squirrels. Presented Third Vertebrate Pest Control Conference. March 1967, San Francisco, Calif.

Matschke, G.H., K.A. Fagerstone, N.D. Halstead, G.K. LaVoie, and D.L. Otis. 1982. Population reduction of Richardson's ground squirrels with zinc phosphide. J. Wildl. Manage. 46:671-677.

Merriam, H.G. 1966. Reproductive potential of prairie dogs. Texas J. Sci. 18:417-419.

Pank, L.F., and G.H. Matschke. 1972. Decline and reinvasion of deer mouse populations after baiting Douglas-fir clear cuts with 6-amenonieotinamide. J. Forest. 70:678-680.
Southwood, T.R.E. 1978. Ecological methods. Second edition. Halsted Press, New York.

Sullins, G.L. 1977. Evaluation of prebaiting for improving bait acceptance by black-tailed prairie dogs. Montana Dept. of Livestock, Helena.

Sullins, G.L. 1980a. Efficacy of strychnine and zinc phosphide baits for controlling black-tailed prairie dogs. Montana Dept. of Livestock, Helena.

Sullins, G.L. 1980 b. A field comparison of strychnine, zinc phosphide, and 1080 grain baits for controlling black-tailed prairie dogs. Montana Dept. of Livestock, Helena.

Sullins, G.L., and B.J. Verts. 1978. Baits and baiting techniques for control of Belding's ground squirrels. J. Wildl. Manage. 42:890-896.

Sullivan, T.P. 1979. Repopulation of clear-cut habitat and conifer seed predation by deer mice. J. Wildl. Manage. 43:861-871.

Tietjen, H.P. 1976. Zinc phosphide - its development as a control agent for black-tailed prairie dogs. U.S. Dept. Inter., Fish and Wildl. Serv. Special Scientific Report, Wildl. No. 195. Washington, D.C.

Tietjen, H.P., and G.H. Matschke. 1982. Aerial prebaiting for management of prairie dogs with zinc phosphide. J. Wildl. Manage. 46:1 108-1112. 